\title{
Efek Pemakaian Economizer Terhadap Peningkatan Efisiensi Boiler Pulverized Pada Unit Pembangkit Listrik Tenaga Uap
}

\author{
Suhardi $^{1, a}$, Kamriani ${ }^{2}$, Suryanto ${ }^{3}$ Jamal $^{4}$ \\ 1,2,3,4 Jurusan Teknik Mesin, Politeknik Negeri Ujung Pandang, Makassar 90245, Indonesia \\ a Suhardi06mks@gmail.com
}

\begin{abstract}
Heat loss in steam power plants (PLTU) is one of the important factors that is very important to consider in the operation of a boiler. This study aims to analyze the efficiency of a pulverized boiler by using an economizer and compare if not using an economizer on a boiler type Pulverized PLTU. In conducting this research the method used is a method using survey data on the Jeneponto steam power plant and followed by an analysis comparing the use of an economizer and without using an economizer. The analysis results obtained boiler efficiency by using an economizer by an average of $90 \%$ and without using an economizer by an average of $80 \%$. Thus the use of an economizer can increase efficiency by about $12 \%$ or the equivalent of $2976.8 \mathrm{~kg} / \mathrm{hour}$.
\end{abstract}

Keywords: Boiler, Heat Loss, Economizer, Efficiency,

\begin{abstract}
Abstrak: Kehilangan panas pada pembangkit listrik tenaga uap (PLTU) merupakan salah satu faktor penting yang sangat perlu diperhatikan dalam pengoperasian boiler. Penelitian ini bertujuan menganalisis efisiensi boiler pulverized dengan memakai economizer dan membandingkan jika tidak memakai economizer pada suatu boiler jenis Pulverized PLTU. Dalam melakukan penelitian ini metode yang digunakan adalah metode dengan menggunakan data hasil survey pada pembangkit listrik tenaga uap (PLTU) Jeneponto dan dilanjutkan dengan analisis yang membandingkan penggunaan economizer dan tanpa menggunakan economizer. Hasil analisis diperoleh efesiensi boiler dengan menggunakan economizer sebesar rata-rata $90 \%$ dan tanpa menggunakan economizer rata-rata $80 \%$. Dengan demikian penggunaan economizer dapat meningkatkan efesiensi sekitar $12 \%$ atau yang setara dengan $2976,8 \mathrm{~kg} / \mathrm{jam}$.
\end{abstract}

Kata kunci : Boiler, Kehilangan Panas, Economizer, Efisiensi

\section{PENDAHULUAN}

Kerugian panas yang terjadi pada gas buang (exhaust) merupakan salah satu faktor penting yang sangat berpengaruh terhadap efisiensi pada unit boiler (steam generator). Konsekuensi logis dari kerugian panas yang hilang atau terbuang berdampak pada faktor ekonomis. Sehubungan dengan itu, penggunaan economizer pada PLTU merupakan salah satu solusi yang dapat digunakan untuk memanfaatkan kalor yang terbawa bersama gas buang yang masih memiliki temperatur yang cukup tinggi yaitu sekitar 700 s.d $1000^{\circ} \mathrm{F}$ atau 370 s.d $537^{\circ} \mathrm{C}$ (M. M. El-Wakil, 1984), sehingga dapat dimanfaatkan kembali untuk memanaskan air umpan sebelum masuk ke boiler. Efek air umpan melewati kondensor temperaturnya naik sehingga dapat mengurangi beban boiler dan dapat menghemat pemakaian bahan bakar.

Sistem kelistrikan Sulselrabar mempunyai sistem pembangkit listrik tenaga uap (PLTU) diantaranya yang berada di kabupaten Jeneponto yang dikelola oleh PT. BOSOWA ENERGI yang memiliki empat unit pembangkit dengan kapasitas desain $2 \times 125$ MW dan $2 \times 135$ MW. Penggunaan bahan bakar sangat mendominasi pembiayaan produksi di perusahaan pembangkit listrik tenaga uap (PLTU) Jeneponto mencakup bagian yang terbesar dari total biaya produksi. Peralatan yang ada di PTLU Jeneponto pada umumnya berumur kurang lebih sepuluh tahun semenjak pendirian pembangkit tersebut. Efisiensi peralatan tersebut menurun sejalan dengan bertambah umur peralatan, ketika efisiensi menurun pemakaian bahan bakar dan hasil yang diperoleh tidak sesuai dengan target produksi.

Penurunan efisiensi menyebabkan kerugian ekonomi dikarenakan harga bahan bakar semakin hari semakin meningkat, oleh karena itu perlu dilakukan peningkatan efisiensi untuk menigkatkan kinerja suatu peralatan, menghemat penggunaan bahan bakar, dan meningkatkan hasil produksi peralatan tersebut. Temperatur gas buang yang dihasilkan pada unit pembangkit listrik tenaga uap (PLTU) Jeneponto diketahui 
memiliki temperatur yang masih tinggi berkisar antara $300^{\circ} \mathrm{C}$ s.d $400^{\circ} \mathrm{C}$ (PLTU Jeneponto, 2018). Temperatur gas buang yang masih tinggi ini dapat dimanfaatkan kembali untuk memanaskan air yang masuk ke dalam boiler. Dengan memanfaatkan kembali gas buang akan dapat menurunkan konsumsi bahan bakar. Salah satu pilihan PLTU Jeneponto dalam meningkatkan efisiensi boiler (steam generator) adalah dengan penggunaan economizer [1].

Penelitian tentang Analisa Pemakaian Economizer terhadap Peningkatan Efisiensi dan Penghematan Bahan Bakar Boiler 052 B101 Unit Pembangkit Tenaga Uap PT. Pertamina (PERSERO) Revinery Unit IV Cilacap. menyimpulkan bahwa berdasarkan penelitan di dapatkan efisiensi boiler dengan menggunakan economizer sebesar 86,97\% sedangkan efisiensi boiler tanpa menggunakan economizer sebesar 76,07\%. Dan dengan menggunakan economizer maka dapat menghemat bahan bakar sebesar 174,08\% [2,3].

Economizer adalah alat pemindah panas berbentuk tubular yang digunakan untuk memanaskan air umpan boiler sebelum masuk ke steam drum. Istilah economizer diambil dari kegunaan alat tersebut, yaitu untuk menghemat (to economizer) penggunaan bahan bakar dengan mengambil panas (recovery) gas buang sebelum dibuang ke atmosfir. Biro Efisiensi Energi (2004) menyatakan bahwa sebuah economizer dapat dipakai untuk memanfaatkan panas gas buang untuk pemanasan awal air umpan boiler. Setiap penurunan $220^{\circ} \mathrm{C}$ suhu gas buang melalui economizer atau pemanas awal terdapat $1 \%$ penghematan bahan bakar dalam boiler. Setiap kenaikan $60{ }^{\circ} \mathrm{C}$ suhu air umpan melalui economizer atau kenaikan $200^{\circ} \mathrm{C}$ suhu udara pembakaran melalui pemanas awal udara, terdapat $1 \%$ penghematan bahan bakar dalam boiler.

\section{Analisis Perhitungan Economizer}

a. Beban Thermal yang diserap oleh air pada economizer

Beban termal untuk setiap pengukuran yang diserap air pada economizer yaitu Qeco, diperoleh dengan menggunakan persamaan berikut;

$$
\begin{aligned}
& Q_{\text {eco }}=m_{\text {air }} \cdot C p_{\text {air }} \cdot \Delta T \\
& Q_{\text {eco }}=m_{\text {air }} \cdot C p_{\text {air }} \cdot(\text { Tout }- \text { Tin })
\end{aligned}
$$

Keterangan :

Qeco = Kalor yang diserap oleh air pada economizer $(\mathrm{kJ} / \mathrm{s})$

$\dot{\mathrm{m}}_{\text {air }}=$ Laju aliran air yang dipanaskan di dalam economizer $(\mathrm{kg} / \mathrm{Jam})$

CPair = Konstanta panas air pada tekanan konstan $(\mathrm{J} / \mathrm{kg} \cdot \mathrm{K})$

$\mathrm{T}_{\text {out }}=$ Temperatur aliran air keluar economizer $(\mathrm{K})$

$\mathrm{T}_{\text {in }}=$ Temperatur aliran masuk economizer $(\mathrm{K})$.

b. Beban Thermal gas buang yang diterima economizer

Beban termal gas buang yang diterima oleh gas economizer yaitu Qgb diperoleh dengan menggunakan persamaan berikut;

$Q_{g b}=m_{g a s} \cdot C p_{g a s} \cdot \Delta T$

$Q_{g b}=m_{g b} \cdot C p_{g a s} \cdot($ Tout - Tin $)$

Keterangan :

$\mathrm{Q} g b=$ Kalor gas buang yang diterima economizer $(\mathrm{kJ} / \mathrm{s})$

$\dot{\mathrm{m}} g b$ = Laju aliran gas yang dipanaskan di dalam economizer $(\mathrm{kg} / \mathrm{Jam})$

$\mathrm{CP} g b=$ Konstanta panas gas pada tekanan konstan $(\mathrm{J} / \mathrm{kg} . \mathrm{K})$

$\mathrm{T}_{\text {out }}=$ Temperatur aliran gas keluar economizer $(\mathrm{K})$

$\mathrm{T}_{\text {in }}=$ Temperatur aliran gas masuk economizer $(\mathrm{K})$.

c. Ratio efektivitas economizer (Reff)

Menghitung harga ratio efektivitas, untuk mengetahui kinerja economizer. dihitung dengan menggunakan persamaan: 
139 Suhardi, Kamriani, Suryanto, Jamal. Efek Pemakaian Economizer Terhadap Peningkatan Efisiensi Boiler Pulverized Pada Unit Pembangkit Listrik Tenaga Uap

$$
R_{e f f}=\frac{Q_{E C O}}{Q_{G B}}
$$

Keterangan :

Reff = Ratio efektivitas economizer $(\%)$

Qeco $=$ Beban Thermal yang diserap oleh air pada economizer $(\mathrm{kJ} / \mathrm{s})$

$\mathrm{Q} g b=$ Beban Thermal gas buang yang diterima economizer

\section{d. Analisis Perhitungan Efisiensi Boiler}

Efisiensi adalah unjuk kerja suatu kemampuan alat utilitas. Disamping itu, definisi efisiensi boiler adalah tingkat kemampuan kerja boiler atau ketel uap yang didapat melalui perbandingan antara energi yang berpindah tempat atau diserap oleh fluida kerja didalam ketel dengan masukan energi kimia dari bahan bakar. Tingkat efisiensi pada boiler atau ketel uap tingkat efisiensinya berkisar antara 70\% hingga 90\%, (Asmudi, 2009).

Parameter yang dipantau untuk perhitungan efisiensi boiler adalah:

- Jumlah steam yang dihasilkan per jam (Q) dalam kg/jam

- Jumlah bahan bakar yang digunakan per jam (q) dalam $\mathrm{kg} / \mathrm{jam}$

- Tekanan uap (dalam Mpa/Bar) dan Temperatur uap $\left({ }^{\circ} \mathrm{C}\right)$

- Suhu air umpan $\left({ }^{\mathrm{O}} \mathrm{C}\right)$

- Jenis bahan bakar dan nilai panas kotor bahan bakar (GCV) dalam kkal/kg bahan bakar

1. Efisiensi boiler menggunkan economizer

$$
\begin{aligned}
\boldsymbol{\eta}_{\text {d.eco }} & =\frac{\text { Panas keluar }}{\text { Panas masuk }} \times 100 \% \\
& =\frac{\dot{m s} \times\left(h_{s}-h_{\text {wieco }}\right)}{\dot{m b b} \times \text { LHVbb }} \times 100 \%
\end{aligned}
$$

2. Efisiensi boiler tanpa economizer

$$
\begin{aligned}
& \boldsymbol{\eta}_{\text {teco }}=\frac{\text { Panas keluar }}{\text { Panas masuk }} \times 100 \% \\
= & \frac{\dot{m} s \times\left(\left(h_{s}-h_{\text {wieco }}\right)-\left(h_{f w}-h_{\text {wi eco }}\right)\right\}}{\dot{m} b b \times L H V b b} \times 100 \%
\end{aligned}
$$

Keterangan :

$\dot{\mathrm{ms}} \quad=$ Jumlah steam yang dihasilkan per jam $(\mathrm{kg} / \mathrm{jam})$

$h_{S} \quad=$ Entalpi steam jenuh $(\mathrm{kJ} / \mathrm{kg})$

$h f_{w} \quad=$ Entalpi air umpan $(\mathrm{kJ} / \mathrm{kg})$

hwi.eco $=$ Entalpi air masuk pada economizer $(\mathrm{kJ} / \mathrm{kg})$

$\operatorname{mb} b \bar{b}=$ Jumlah massa bahan bakar yang digunakan per jam (kg/jam)

$L H V b b=$ Nilai kalor bahan bakar $(\mathrm{kkal} / \mathrm{kg})$

3. Panas (Q) yang dibutuhkan dalam proses pembentukan uap dalam boiler

a. Dengan menggunakan economizer

$$
\mathrm{Q}_{\text {d.eco }}=\mathrm{m} u \times(h s-h f w)
$$

b. Tanpa menggunakan economizer

$$
\mathrm{Q}_{\text {teco }}=\dot{\mathrm{m}} u \times(\text { hs }- \text { hwieco })
$$

4. Penggunaan Bahan bakar $\left(\dot{\mathrm{m}}_{\boldsymbol{b} b}\right)$

a. Dengan menggunakan economizer 


$$
\dot{\mathrm{m}}_{b b}=\frac{Q}{L H V b b \times n_{\text {dleco }}} \times 100 \%
$$

b. Tanpa menggunakan economizer

$$
\dot{\mathrm{m}}_{b b}=\frac{Q}{L H V b b \times n_{\text {t.eco }}} \times 100 \%
$$

\section{METODE PENELITIAN}

Dalam melakukan penelitian ini metode yang digunakan adalah dengan menggunakan data real hasil survey pada pembangkit listrik tenaga uap (PLTU) Jeneponto dilanjutkan dengan analisis yang membandingkan penggunaan Economizer dan tanpa menggunakan Economizer. Adapun parameter-parameter yang akan di catat pada saat penelitian sebagai berikut;

Tabel. 1 Spesifikasi Economizer PLTU Jeneponto unit $2 \times 125 \mathrm{MW}$

\begin{tabular}{|l|r|r|}
\hline \multicolumn{1}{|c|}{ Parameter } & Nilai & \multicolumn{1}{c|}{ Satuan } \\
\hline Heating surface & - & $\mathrm{mm}^{2}$ \\
\hline Tube diameter $\times$ min thickness & $32 \times 4$ & $\mathrm{~mm}$ \\
\hline Tube length & 1800 & $\mathrm{~m}^{2}$ \\
\hline Tube material & 20 & $\mathrm{G}$ \\
\hline Inlet gas temperature & 300 & ${ }^{\circ} \mathrm{C}$ \\
\hline Outlet gas temperature & 130 & ${ }^{\circ} \mathrm{C}$ \\
\hline Inlet water temperature & 250 & ${ }^{\circ} \mathrm{C}$ \\
\hline Outlet water temperature & 330 & ${ }^{\circ} \mathrm{C}$ \\
\hline Inlet water pressure & 14.22 & $\mathrm{Mpa}$ \\
\hline Outlet water pressure & 13.8 & $\mathrm{Mpa}$ \\
\hline Flow rate water & 400 & ton/hour \\
\hline
\end{tabular}

Tabel. 2 Spesifikasi Boiler PLTU Jeneponto unit $2 \times 125 \mathrm{MW}$

\begin{tabular}{|l|r|r|}
\hline \multicolumn{1}{|c|}{ Parameter } & \multicolumn{1}{c|}{ Nilai } & \multicolumn{1}{c|}{ Satuan } \\
\hline Steam Flow at boiler outlet & 410 & Ton/hour \\
\hline Heat output & 125 & $\mathrm{MW}$ \\
\hline Steam temperature at boiler inlet & 330 & ${ }^{\circ} \mathrm{C}$ \\
\hline Steam temperature at boiler outlet & 540 & ${ }^{\circ} \mathrm{C}$ \\
\hline Steam pressure at boiler inlet & 12.2 & $\mathrm{Mpa}$ \\
\hline Steam pressure at boiler outlet & 13.8 & $\mathrm{Mpa}$ \\
\hline Total boiler heating surface area & 1848.6 & $\mathrm{~m}^{2}$ \\
\hline Heating surface area of fire tub section & 1894 & $\mathrm{~m}^{2}$ \\
\hline Fuel & Coal & \\
\hline Fuel gross calorific value GVC & 4500 & $\mathrm{Kcal} / \mathrm{kg}$ \\
\hline Flow rate water & 400 & ton $/ \mathrm{hour}$ \\
\hline
\end{tabular}

\section{HASIL DAN PEMBAHASAN}

\section{A. Efisiensi Boiler}

Pada Gambar 1 s.d 3 menunjukkan bahwa hubungan antara efisiensi boiler terhadap energi input bahan bakar, dapat diketahui bahwa efisiensi boiler berbanding terbalik dengan energi input bahan bakar yang digunakan, dimana semakin sedikit energi input bahan bakar yang digunakan maka efisiensi boiler semakin besar, sebaliknya semakin besar energi input bahan bakar yang digunakan maka efisiensi boiler semakin kecil. Dari gambar 3.3 terlihat bahwa efisiensi boiler dengan menggunakan economizer lebih besar yaitu sebesar 92\% dibandingkan dengan efisiensi boiler tanpa economizer yaitu $80 \%$ pada beban $60 \mathrm{MW}$, dari gambar 3.4 juga terlihat efisiensi boiler dengan menggunakan economizer lebih besar yaitu sebesar 90\% dibandingkan dengan efisiensi boiler tanpa economizer yaitu $78 \%$ pada beban $80 \mathrm{MW}$, dan terlihat juga dari gambar 3.5 bahwa efisiensi boiler dengan menggunakan economizer lebih besar yaitu sebesar $68 \%$ dibandingkan dengan efisiensi boiler 
141 Suhardi, Kamriani, Suryanto, Jamal. Efek Pemakaian Economizer Terhadap Peningkatan Efisiensi Boiler Pulverized Pada Unit Pembangkit Listrik Tenaga Uap

tanpa economizer yaitu 62\% untuk beban 100 MW. Sehingga dapat dikatakan bahwa dengan pemakaian economizer dengan memanfaatkan gas buang dari boiler maka dapat meningkatkan efisiensi dari kerja boiler, hal ini dikarenakan temperatur air sebelum dibakar di dalam boiler sudah cukup tinggi, sehingga pemanasan air menjadi uap di dalam boiler tidak memakan waktu lama dan tidak menggunakan bahan bakar yang banyak untuk mencapai standar temperatur yang telah ditentukan.

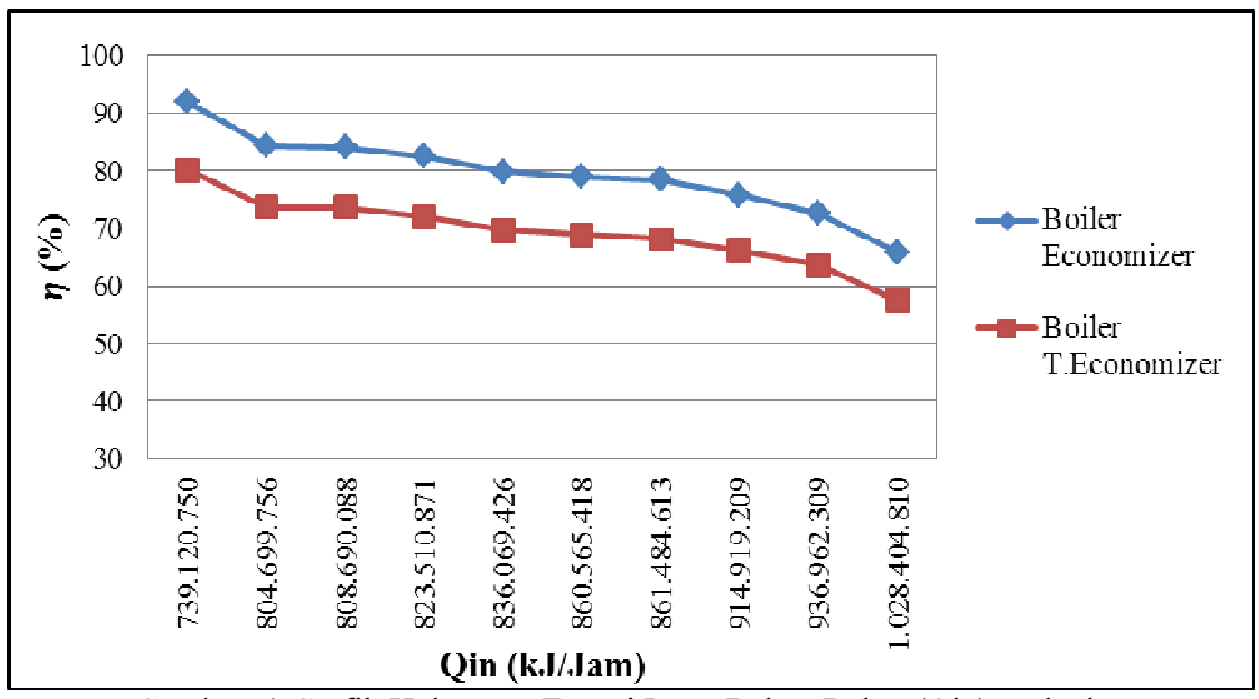

Gambar. 1 Grafik Hubungan Energi Input Bahan Bakar (Qin) terhadap Efisiensi Boiler (n) pada beban $60 \mathrm{MW}$ dengan mbb $39000-47000 \mathrm{~kg} / \mathrm{jam}$

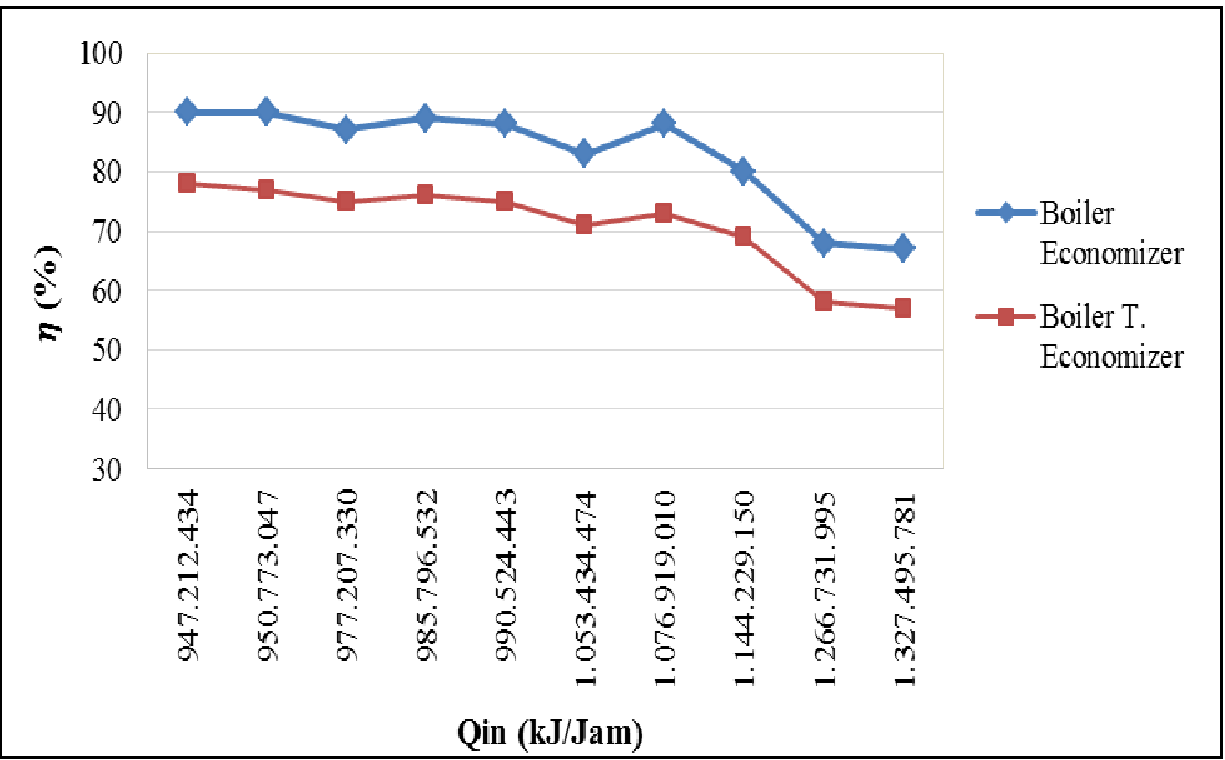

Gambar. 2 Grafik Hubungan Energi Input Bahan Bakar (Qin) terhadap Efisiensi Boiler (n) pada beban $80 \mathrm{MW}$ dengan mbb $45000-65000 \mathrm{~kg} / \mathrm{jam}$ 


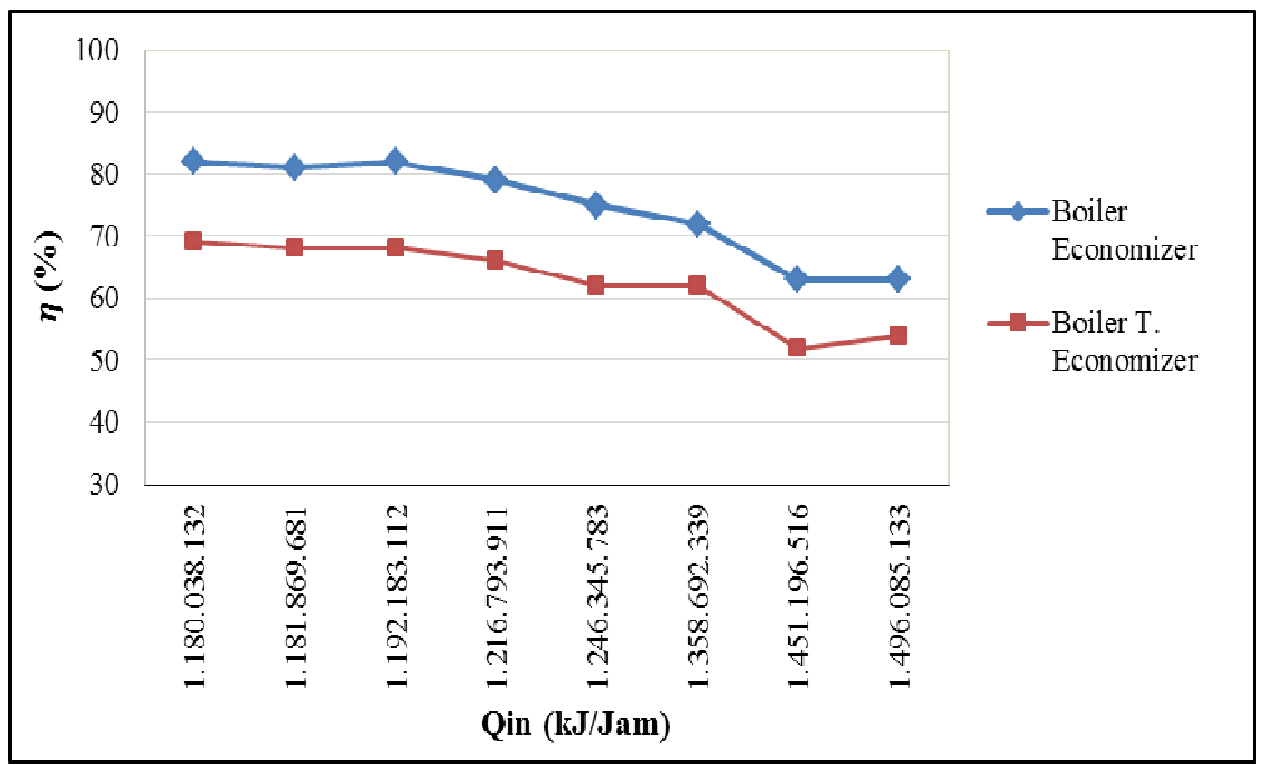

Gambar 3 Grafik Hubungan Energi Input Bahan Bakar (Qin) terhadap Efisiensi Boiler (n) pada beban 100 MW dengan mbb 55000 - 70000 kg/jam

\section{A. Penggunaan Bahan Bakar}

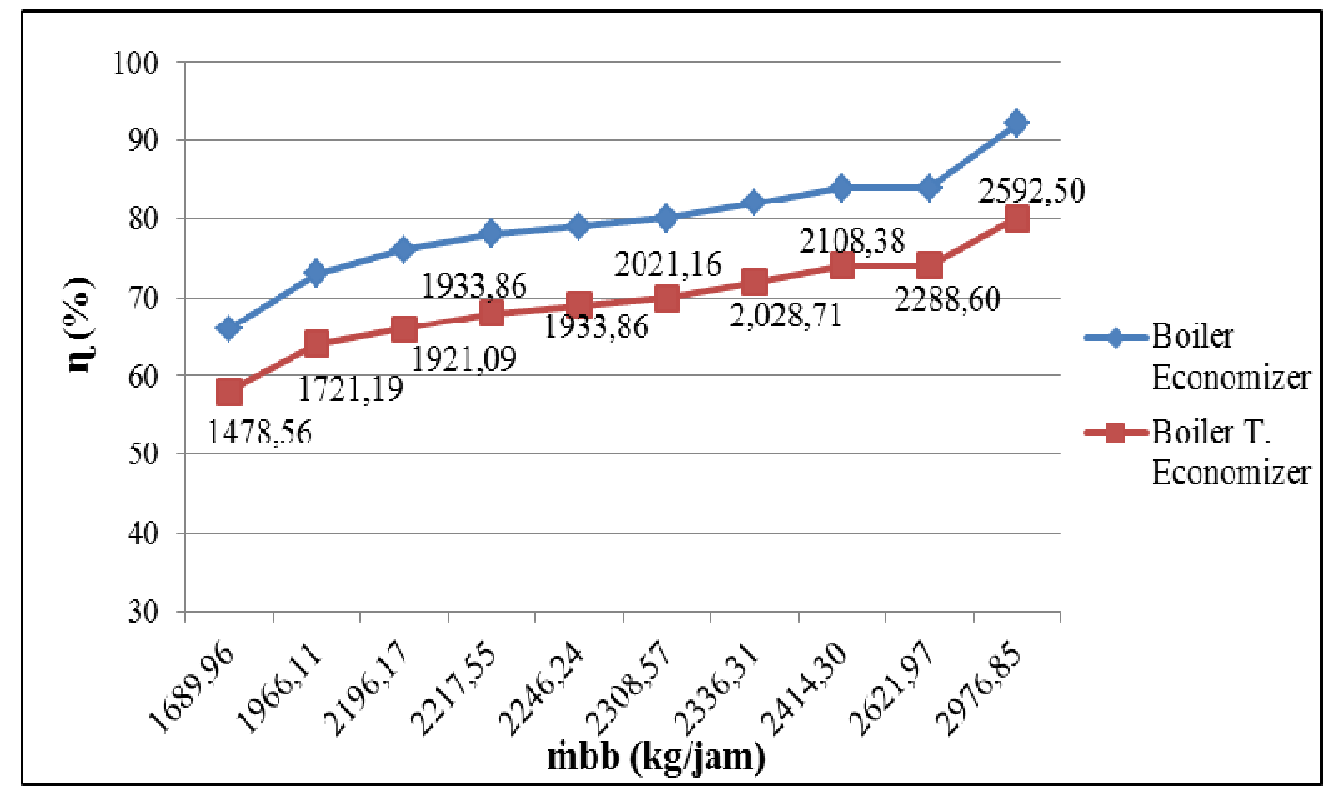

Gambar 4 Grafik Hubungan Penghematan Bahan Bakar Boiler terhadap Efisiensi Boiler ( $\eta$ ) pada beban $60 \mathrm{MW}$ 
143 Suhardi, Kamriani, Suryanto, Jamal. Efek Pemakaian Economizer Terhadap Peningkatan Efisiensi Boiler Pulverized Pada Unit Pembangkit Listrik Tenaga Uap

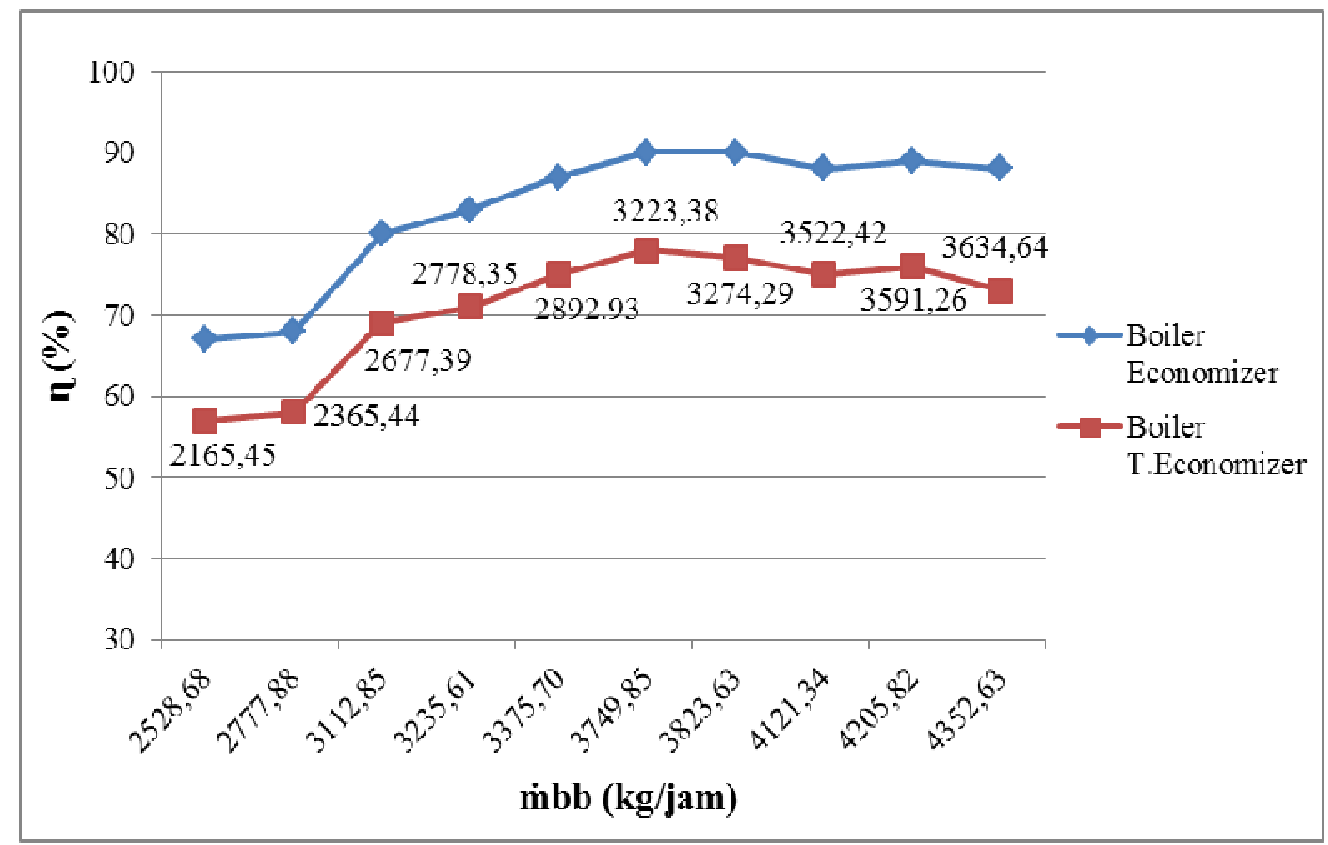

Gambar 5 Grafik Hubungan Penghematan Bahan Bakar Boiler terhadap Efisiensi Boiler (n) pada beban $80 \mathrm{MW}$

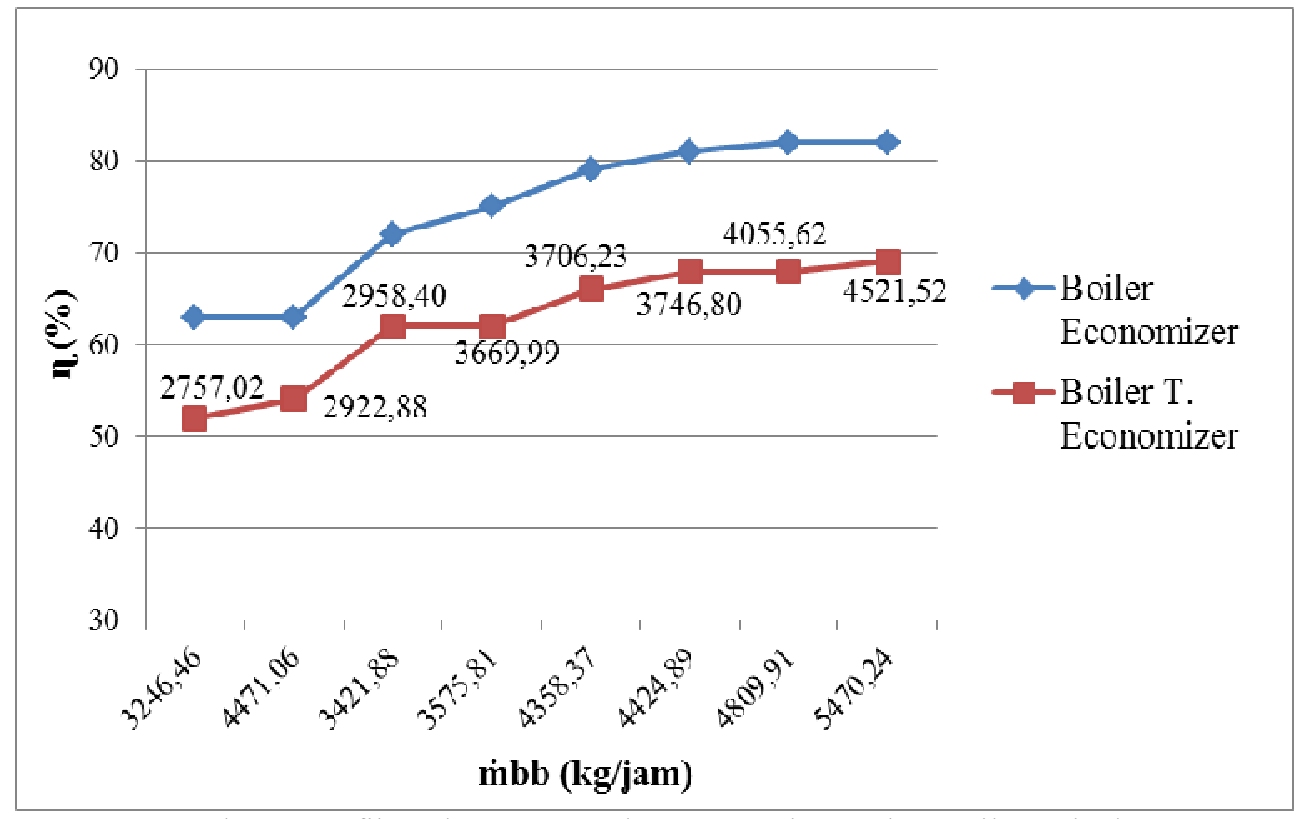

Gambar 6 Grafik Hubungan Penghematan Bahan Bakar Boiler terhadap

Efisiensi Boiler ( $\mathrm{n}$ ) pada beban $100 \mathrm{MW}$

Pada Gambar 4 s.d 6 terlihat bahwa hubungan efisiensi boiler terhadap penghematan bahan bakar yaitu berbanding lurus dimana semakin besar penghematan bahan bakar maka semakin besar juga efisiensi boiler yang dihasilkan. sebaliknya tanpa economizer maka dapat meningkatkan penghematan bahan bakar. Pada gambar 3.6 terlihat bahwa dengan pemakaian economizer dapat menghemat bahan bakar sebesar $2976,85 \mathrm{~kg} / \mathrm{jam}$ dan mampu mengkatkan efisiensi boiler sebesar $92 \%$ sedangkan tanpa economizer tidak dapat meningkatkan penghematan bahan bakar hanya $2592,50 \mathrm{~kg} / \mathrm{jam}$ dengan efisiensi $80 \%$ pada beban $60 \mathrm{MW}$, Pada gambar 3.7 
terlihat juga bahwa dengan pemakaian economizer dapat meningkatkan penghematan bahan bakar sebesar 4352,63 kg/jam dan mampu mengkatkan efisiensi boiler sebesar $88 \%$ sedangkan tanpa economizer tidak dapat meningkatkan penghematan bahan bakar hanya 3634,64 kg/jam dengan efisiensi $80 \%$ pada beban $80 \mathrm{MW}$, dan Pada gambar 3.8 terlihat bahwa dengan pemakaian economizer dapat meningkatkan bahan bakar sebesar 5470,24 kg/jam dan mampu meningkatkan efisiensi boiler sebesar 75\% sedangkan tanpa economizer tidak dapat meningkatkan penghematan bahan bakar hanya 4521,52 kg/jam dengan efisiensi $69 \%$ pada beban $100 \mathrm{MW}$.

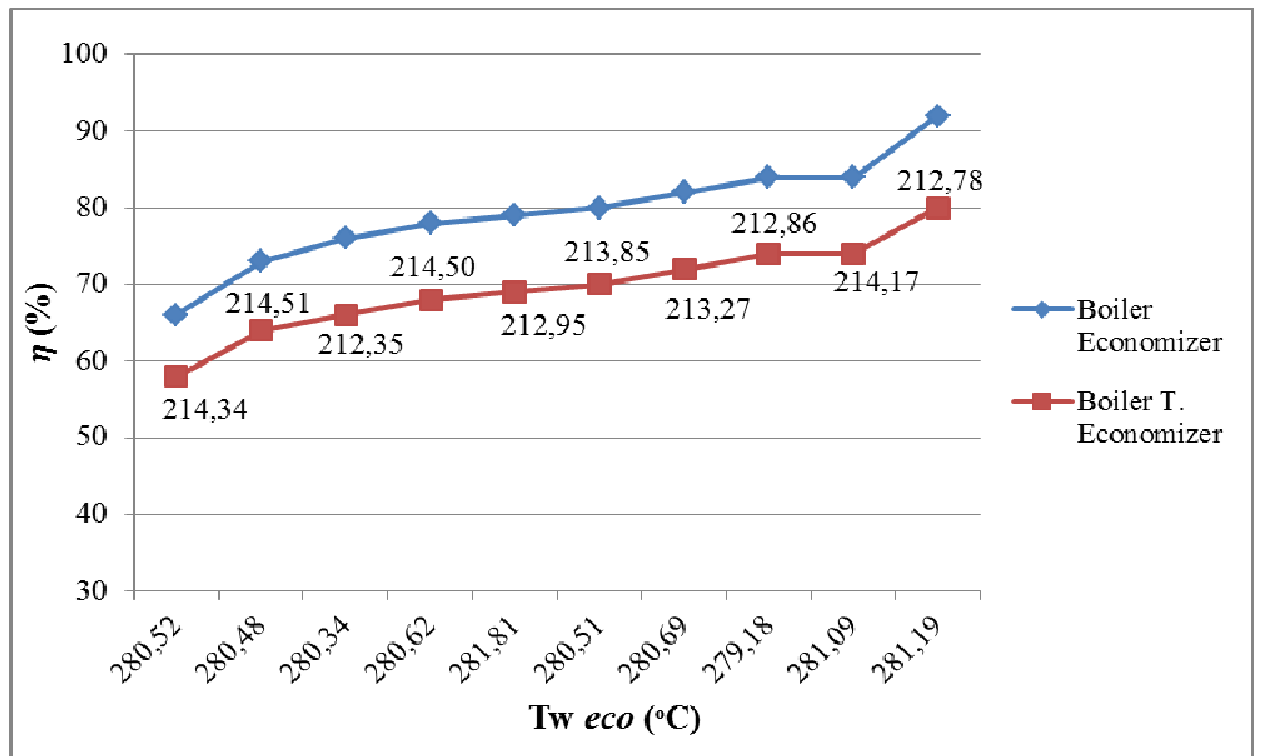

Gambar 7 Grafik Hubungan Temperatur Air Economizer (Tweco) terhadap Efisiensi Boiler (n) pada $60 \mathrm{MW}$

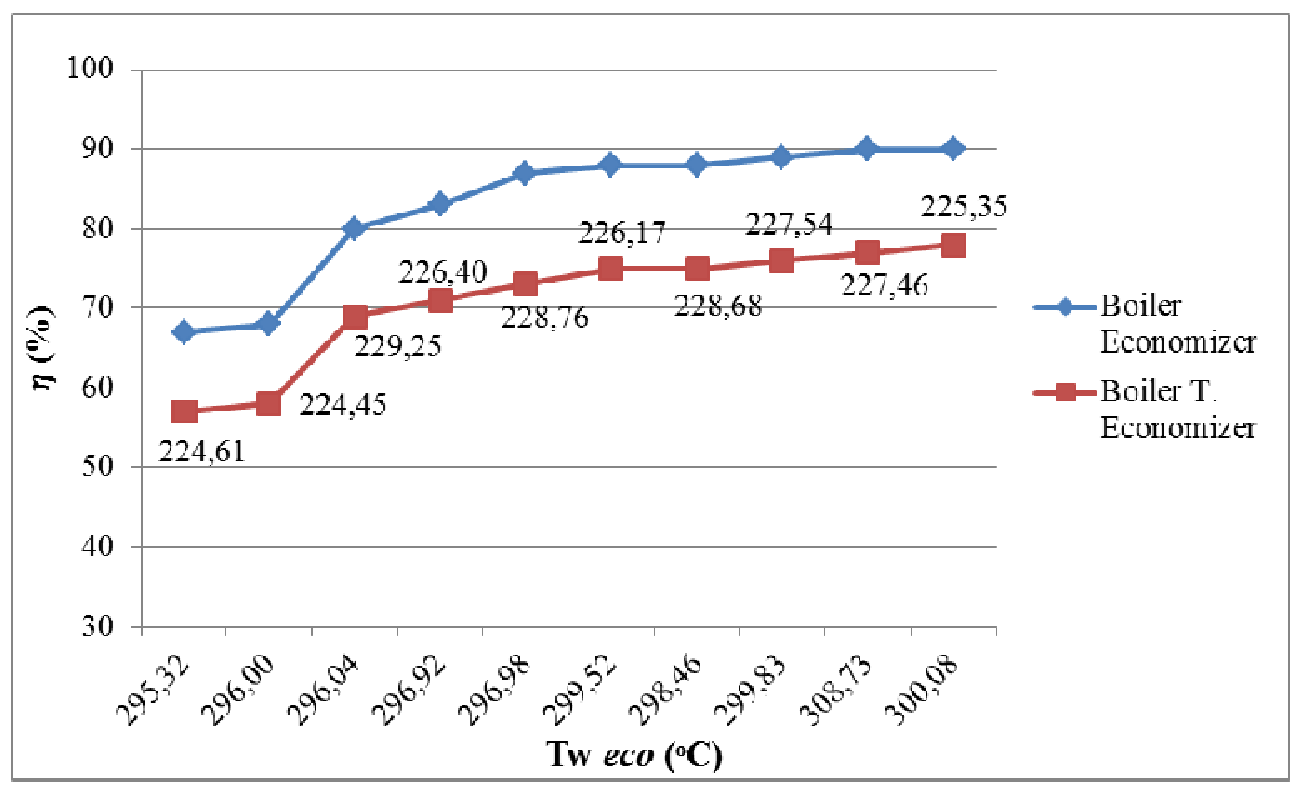

Gambar 8 Grafik Hubungan Temperatur Air Economizer (Tweco) terhadap Efisiensi Boiler ( $\eta$ pada $80 \mathrm{MW}$ 
145 Suhardi, Kamriani, Suryanto, Jamal. Efek Pemakaian Economizer Terhadap Peningkatan Efisiensi Boiler Pulverized Pada Unit Pembangkit Listrik Tenaga Uap

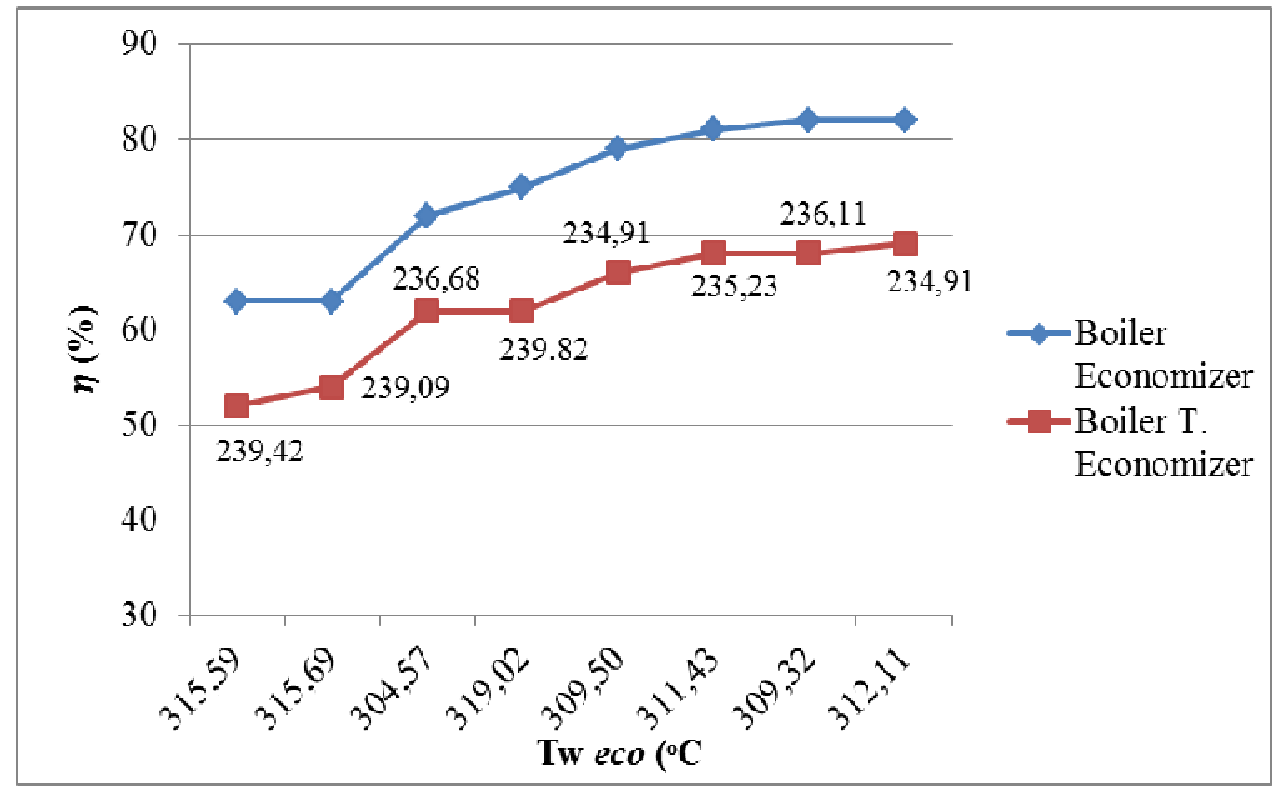

Gambar 9 Grafik Hubungan Temperatur Air Economizer (Tweco) terhadap Efisiensi Boiler (n) pada $100 \mathrm{MW}$

Pada Gambar 7 s.d 9 menunjukkan bahwa perbandingan antara temperatur air economizer terhadap efisiensi boiler dengan pemakaian economizer dan tanpa economizer, terlihat bahwa dengan pemakaian economizer dengan memanfaatkan gas buang dari boiler dapat meningkatkan temperatur air umpan boiler sehingga dapat menaikkan efisiensi boiler. Pada gambar 3.9 terlihat bahwa dengan pemakaian economizer dapat meningkatkan temperatur air umpan boiler sebesar $281,19{ }^{\circ} \mathrm{C}$ dan mampu mengkatkan efisiensi boiler sebesar 92\% sedangkan tanpa economizer temperatur air umpan boiler yang dihasilkan lebih rendah yaitu $212,78{ }^{\circ} \mathrm{C}$ dengan efisiensi $80 \%$ pada beban $60 \mathrm{MW}$, Pada gambar 3.10 terlihat juga bahwa dengan pemakaian economizer dapat meningkatkan temperatur air umpan sebesar $300{ }^{\circ} \mathrm{C}$ dan mampu mengkatkan efisiensi boiler sebesar $90 \%$ sedangkan tanpa economizer temperatur air umpan boiler yang dihasilkan lebih rendah yaitu $235,35^{\circ} \mathrm{C}$ dengan efisiensi $78 \%$ pada beban $80 \mathrm{MW}$, dan Pada gambar 3.11 terlihat bahwa dengan pemakaian economizer dapat meningkatkan temperatur air umpan sebesar 312,11 ${ }^{\circ} \mathrm{C}$ dan mampu meningkatkan efisiensi boiler sebesar $82 \%$ sedangkan tanpa economizer temperatur air umpan boiler yang dihasilkan lebih rendah yaitu $234,91{ }^{\circ} \mathrm{C}$ dengan efisiensi $78 \%$ pada beban $100 \mathrm{MW}$.

Hal ini dikarenakan temperatur air sebelum dibakar di dalam boiler sudah cukup tinggi, sehingga pemanasan air menjadi steam di dalam boiler tidak memakan waktu lama dan tidak menggunakan bahan bakar yang banyak untuk mencapai standar temperatur yang telah ditentukan, maka biaya operasional dapat lebih di efisienkan dan secara tidak langsung dapat menguntungkan bagi perusahaan. Selain itu dengan bertambahnya efisiensi boiler temperatur air akan mengurangi kadar $\mathrm{O}_{2}$ dan $\mathrm{N}_{2}$ yang terkandung dalam air umpan boiler

Dari Gambar 7 s.d 9 jelas terlihat bahwa tanpa pemakaian economizer maka efisiensi kerja boiler menurun, dalam artian tanpa pemanasan yang dibantu oleh economizer, boiler harus bekerja lebih lama dalam menghasilkan uap dan selain itu boiler akan memerlukan bahan bakar yang lebih banyak untuk mencapai panas temperatur uap yang telah ditentukan.

\section{B. Efektivitas Economizer}




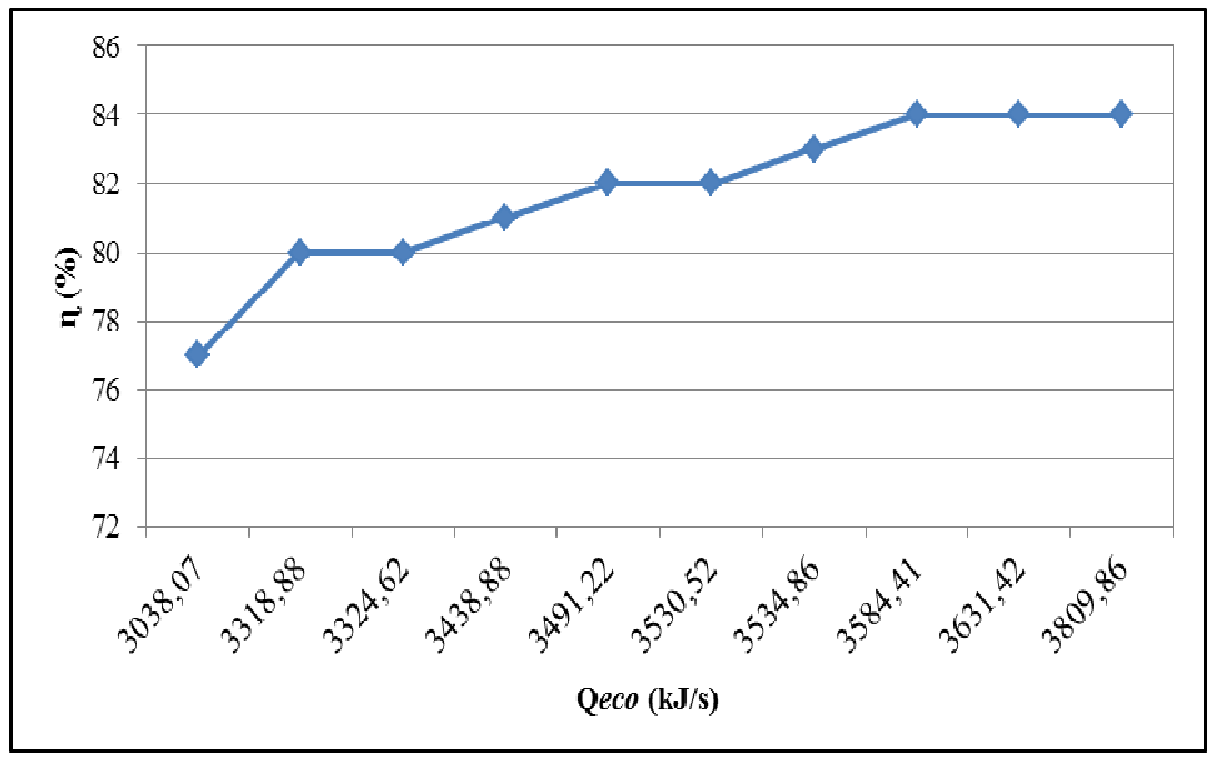

Gambar 10 Grafik Hubungan Energi Panas yang diserap Air (Qeco) terhadap Efisiensi Boiler ( $\mathrm{n}$ ) dengan (Qin) $800.000 \mathrm{kj} / \mathrm{jam}-850.000 \mathrm{kj} / \mathrm{jam}$

Pada Gambar 10 terlihat hubungan energi panas yang diserap air pada economizer terhadap efisiensi boiler yaitu berbanding lurus dimana semakin besar energi panas yang diserap air pada economizer maka efisiensi boiler semakin besar. Sehingga dapat dikatakan bahwa dengan pemakaian economizer pada boiler mampu meningkatkan energi panas pada air umpan boiler, sehingga pemanasan air menjadi uap di dalam boiler tidak memakan waktu lama dan tidak menggunakan bahan bakar yang banyak untuk mencapai standar temperatur pada boiler yang telah ditentukan. terlihat bahwa energi panas yang diserap air sebesar 3809,86 kJ/s mampu meningkatkan efisiensi boiler sebesar $84 \%$, untuk energi input bahan bakar yang cenderung meningkat.

\section{KESIMPULAN DAN SARAN}

\section{A. Kesimpulan}

Dari hasil analisis data dan pembahasan yang telah dilakukan pada bab sebelumnya, maka dapat disimpulkan :

1. Pada Pembangkit Listrik Tenaga Uap (PLTU), dengan pemakaian economizer (pemanas air pengisi boiler) dapat meningkatkan efesiensi boiler. Dengan pemakaian economizer efesiensi boiler sebesar $92 \%$ sedangkan tanpa economizer efesiansi boiler sebesar $80 \%$. Dengan panas yang dibutuhkan untuk proses pembentukan air menjadi uap sebesar $468.534 .82 \mathrm{kj} / \mathrm{jam}$.

2. Dengan pemakaian economizer, maka pemanfaatan gas buang dari boiler dapat meningkatkan temperatur air umpan boiler sehingga dapat menaikkan efisiensi boiler sebesar kurang lebih $12 \%$, sehingga dapat mengurangi biaya bahan bakar dan menghemat biaya operasional yang lain seperti pemakaian chemical untuk mengurangi kadar $\mathrm{O}_{2}$ dan $\mathrm{N}_{2}$ yang terkandung dalam air umpan boiler.

\section{DAFTAR PUSTAKA}

[1] ASME Power Test Codes 13.2, "Test Code for Steam Generating Unit"

[2] Biro Efisiensi Energi. 2004. Pemanfaatan Kembali Limbah Panas. Retrieved from http://www.energyefficiecyasia.org, on 30th November 2015. 
147 Suhardi, Kamriani, Suryanto, Jamal. Efek Pemakaian Economizer Terhadap Peningkatan Efisiensi Boiler Pulverized Pada Unit Pembangkit Listrik Tenaga Uap

[3] Budi Rahman. 2011. Kajian Efektivitas Economizer Pada Sistem Boiler Kpasitas 20 TON/Jam dan Tekanan 20 Barg. Jurnal Ilmiah Teknobiz Vol.5 No.2: PT. Basuki Pratama Engineering: Jakarta.

[4] Cengel, Y dan M. Boles. 1994. Thermodynamic An Engineering Approach. Fifth edition. McGraw-Hill Book. New York. (Online), (https://cruncheez.files.wordpress.com), diakses 2 Januari 2019.

[5] Holman, J.P., Jasjfi. E. 1997. Perpindahan Kalor Edisi Keenam. Jakarta : Erlangga

[6] M.M El-wakil. 1985. PowerPlant Technology. International Edition.

Singapore McGraw-Hill. (Online), (https://www.brijrbedu.org), diakses 2 Januari 2019.

[7] Nurmalita. 2012. Analisis Efisiensi Energi Pada PLTU PT. Energi Alamraya Semesta di Kabupaten Nagong Raya Nanggroe Aceh Darussalam. Laporan Skripsi : Departemen Teknik Mesin dan Biosistem : Institute Pertanian Bogor (IPB)

[8] Prakoso Rangga. 2018. Kapasitas Pembangkit Listrik Tenaga Uap (PLTU) Indonesia. Laporan akhir. Semarang: Jurusan Teknik Mesin Politeknik Negeri Surabaya

[9] Perusahaan Umum Listrik Negara. 1987. Standar Operasi Pusat Listrik Tenaga Uap Bagian Dua : Faktor-Faktor Pengusahaan, SPLN 62 - 2: 1987.

[10] Perusahaan Umum Listrik Negara. 2009. Rencana Umum Ketenagalistrikan Nasional (RUKN).

[11] Sunyoto, Karnowo, S. M. Bondan Respati. 2008. Teknik Mesin Industri Jilid 3. Jakarta : Direktorat Pembinaan Sekolah Menengah Kejuruan

[12] Sigit P. Kurniawan. 2015. Desain Economizer Untuk Meningkatkan Efisiensi Boiler 52 B 1/2/3 Pada Unit Utilites Kompleks di PT Pertamina RU IV Cilacap. Jurnal Teknik Pomits. Surabaya : Jurusan Teknik Fisika Institute Teknologi Sepuluh November (ITS). 